\title{
Current Situation and Development Prospect of French Economic Reform
}

\author{
Lu Chen \\ School of Economics; School of Foreign Language, Harbin University of Commerce, China \\ chenluhit@sina.com
}

Keywords: French economy; Economic reform; Development prospect

\begin{abstract}
Since the debt crisis in Europe, the French economy remains in the doldrums, and it has not yet appeared any hopeful sign of recovery. France is considered as the second-largest economy in Europe, with the label "European sick man", even "French recession" is rampant. For the French government, the introduction of the revitalization measures, the implementation of structural reform have become an imperative. As the President Hollande had called "The change is now", the French government started to show an attitude of comprehensive reform, and sought to reshape the economic competitiveness. However, in a global environment where economic growth is sluggish, the French government has to face with tremendous pressure, both inside and out, and the reform process is still struggling.
\end{abstract}

\section{Current Situation of French Economic Development}

In recent years, the French economy has gradually slowed down. According to the French National Bureau of Statistics, the statistics show that after a brief rapid growth of the French economy in the first quarter of 2016, but in the following third quarter, it shows a moderate upward trend, with only 0.2 percent uplift of the economic growth. Based on such situation, the French government had to revise the previous growth expectations and reduce the GDP growth from 1.5 percent to 1.4. The reason for this condition is mainly because of the government and the people are deeply disappointed with the economic growth, in the previous two quarters.

The long-term economic stagnation has caused the high deficit in France and the high rate of unemployment and other complicated diseases. At the same time, the economic difficulties caused by the chain reaction triggered a political crisis, both inside and outside.

First of all, the economic recovery is weak, the fiscal deficit remains high. France and Germany have always been regarded as "dual engines" of European economies. In fact, France is far less powerful than Germany in terms of the solid economic foundation and steady economic growth. Since the establishment of the euro zone, France's per capita GDP growth rate of only 0.8 percent, significantly lower than the 1.3 percent in Germany[1]. France's GDP grew at a rate of 0.4 percent in 2014, and only marginally better than 0.3 percent in 2013. This is far below the growth rate of nearly 1.3 percent in Germany and below the average of 0.8 percent in the euro area. At the same time, France's fiscal deficit is the highest among all the euro-zone countries, with public debt still expanding. In 2015, French budget draft announced that, in taking measures to reduce public expenditure and reduce the French deficit, the deficit rate would still be as high as 4.3 percent[2].

Second, the unemployment rate continued to rise. Although France is the EU's second-largest economy, its economic growth has been far off in recent years. Lagging behind other EU countries. According to statistics, the economic growth rate of France in 2015 was only 1.1 percent. The United Kingdom's economic grow rate was 2.2 percent in 2015, Germany's economic growth rate of 1.7 at the same time. There is a close relationship between the slowdown in France's economic growth and the long-term high unemployment rate. It is understood that the unemployment rate in France in recent years has always been hovering around 10 percent. Such a high rate of unemployment seriously affects the pace of economic growth in France. Despite the president's reduction of unemployment as a top priority in his mission, However, the job market in France has seen no improvement but the unemployment rate has been on the rise. The unemployment rate in 
the third quarter of 2014 was 10.4 percent, reaching a new high of 15 years[3]. With the high unemployment rate, especially the youth unemployment problem has not been resolved for a long time, the public dissatisfaction with the government continues to rise.

Third, industrial regression, industrial hollowing intensified. Strong industrial competitiveness has always been the French pride, from Concord to high-speed trains, from Ariane Rockets to nuclear power plants, French industry left a deep impression on the world. However, the French industry as a whole has seen a huge retrogression in the last decade: the loss of 750,000 jobs in the industrial sector. Industry in GDP share declined by 4 percentage points, resulting in a trade deficit of 60 billion euros[4]. At the same time, the French industry became more hollow. According to statistics, more than ten thousand French workers in large enterprise, 80 percent of its employees and 88 percent of the profit are overseas[5].

Fourth, economic difficulties trigger internal and external political crisis. In France, the government support rate continued to decline, both the left and right opposition parties have urged Mr. president to take more effective reform measures. However, the internal polarization of the Social Party and the left-wing opposition to president's policy economic reform have been heard. At the same time, the social contradictions caused by the prolonged sluggish economy have intensified, coupled with the face that France continues to carry our military operations in Mali, Libya and other African countries and regions, to stimulate the desire of extremist organizations to retaliate, the French terriost attacks occur one after another. "France is facing an unprecedented threat of Islamic terrorism"[6]

\section{Reasons for the Slowdown in French Economy}

Heavy tax and light savings, long-term imbalance between revenue and expenditure. Since 1974, France has not now account surplus, long-term public spending accounted for about half of the state financial expenditure. In 2013, the French government spending accounted for 57 percent GDP, ranking first in the euro zone countries, the proportion of social security expenditure is far higher than the European average deficit of 12.5 billion euros. In the case of sluggish economic growth and an aging population, the financial burden is even greater. The French people are accustomed to the high welfare of a comfortable life, any policy of spending cuts will be strongly opposed by the people, in particular, cuts in social welfare and pension expenses have been politically taboo.

The burden of enterprises is heavy and the labor market is rigid. The tax burden of French enterprises is higher than that of other EU countries, foreign companies even criticized France for its tax burden as much as a thousand cakes, and the pressure was fiercer than tigers. From the labor cost perspective, the cost of labor in France is much higher than that of Germany. According to statistics, the average price of labor in France in 2014 was 36 euros per hour, Germany is 31 euros per hour[7]. From the perspective of labor policy, the average working hours per person is short, and the cost of dismissing employees is high. At the same time, the cost of dismissing employees in France is much higher than the cost of hiring new employees.

Lagging industrial development, employment is not balanced. France has entered the era of service economy. From the industrial structure, the French industry has dropped to France's second-largest pillar industries. The first pillar industry service sector has absorbed more than 70 percent of the workforce in France. From the type of enterprise, the French micro and small enterprises are the majority. Economists believe that France lacks medium-sized enterprises, and 20-250 enterprises account for 64.4 percent of the total number of enterprises, in Germany, the ratio was 48 percent. At the same time, there is a lack of close cooperation between large French enterprises and small and medium enterprises. Exports cannot be built on a broader and firmer foundation.

\section{Measures to Promote Economic Reform in France}

Take relevant measures to increase employment rate. In October 2016, the total unemployment rate in France decreased by 11,700. The French government has implanted a lot of initiatives to promote 
employment, such as: small and medium-sized enterprise recruitment subsidy; liability convention; employment competitiveness law. Although the results are significant, but, as the end of October 2016, there are still 3.788 million unemployed people in France. The French government should actively encourage people to start their own businesses, and the government should give preferential tax to enterprises which attract more employments

French leaders should adopt actively vigorous economic measures. For France, it is necessary to promote the healthy, long-term and sustainable development of its economy, these leaders must shoulder more important responsibilities. The French leaders should pay enough attention to the actual situation of the slowdown of their economy. They should carefully analyze the real causes of the slowdown in France, and take a series of measures to stimulate the rapid economic development for specific reasons. French leaders should actively support the cooperation between French enterprises and the world's second largest economies, actively seek development in cooperation. French companies can actively invest in China and continue to promote their economic growth through investment in China. In addition, the French leaders should actively promote and welcome Chinese businessmen to invest in France, to achieve mutual benefit and win-win, so as to effectively promote the rapid growth of the economy.

Advocacy of the public to participate more actively in the work. In order to promote the continuous growth of French economy, the government should actively promote people to participate in their work more actively, create more production value, and make important contributions to the economic development of France. In this process, the media should also actively assume corresponding responsibility. Through a series of news reports, the French people clearly realized that the lack of work is detrimental to the country's economic growth. If the country's economic growth rate continues to slow down, or even a serious decline, but also to a certain extent affect the social welfare, even social security efforts. After knowing this, it is believed that more and more French people will abandon the original weak state of work, and then participate in daily work with a more active attitude, create more value for the country, and continuously promote the continuous growth of the French economy.

Actively carry out the innovation of science and technology. After the $21^{\text {st }}$ century, France's industry development stagnated. Lacking of technological innovation is reflected not only in the automotive sector, in many fields have the same performance. In order to promote the sustainable development of the French economy, France needs to pay more attention and make more efforts in scientific and technological innovation. "The New French Industrial" strategy has been put forward in September 2013. Under the guidance of this strategy, more enterprises and scientific research institutions in France are actively involved in the team of scientific and technological innovation. In spite of this, the scientific and technological innovation achieved so far is not obvious. In this case, the French government should actively advocate scientific and technological innovation, and adopt a series of policies and measures to promote the development of science and technology. Through continuous innovation of science and technology, the French industry will rebound, finally make an important contribution to the economic development of France.

\section{Summary}

In a word, the slowdown in economic growth in France in recent years has been an indisputable fact. The main reasons for the slowdown of French economic growth are: plagued by unemployment, poor government leadership, lack of public work and lack of scientific and technological innovation. In order to promote the rapid growth of the French economy, the French government needs more efforts in the following aspects: take relevant measures to improve the employment rate; leaders should take effective economic measures; advocating people to participate more actively in the work; carrying our more scientific and technological innovation. As long as we can conscientiously do a good job in these areas, we believe France's economy will certainly grow faster and faster. 


\section{References}

[1] “Can François Do a Gerhard?" The Economist, January11, 2014.

[2] "Le FMI conforte la prévision de croissance de la France pour 2015",http://www.challenges.fr/economie/20141007.CHA8617/le-fmiconforte-la-prevision-decroissance-du-gouvernement-pour-2015.html

[3] INSEE, http://www.insee.fr/fr/themes/info-rapide.asp?id=14

[4] Palais de l'Elysée, "Intervention du président de la Républiquesur la nouvelle France industrielle",http://www.elysee.fr/assets/pdf/intervention-du-president-de-la-republique-sur-la-n ouvelle-franceindustrielle.pdf

[5] Information on http://paper.people.com.cn

[6] Information on http://www.lemonde.fr

[7] Information on http://www.coe-rexecode.fr 